\title{
VIII. EURÓPAI ELMÉLETI- ÉS KVANTITATÍV FÖLDRAJZI KOLLOKVIUM
}

\author{
8th European Theoretical and Quantitative \\ Geographical Colloquium \\ (1993. szeptember 12-16, Budapest)
} \begin{abstract}
vényt Budapesten.
\section{A kollokvium témája:}

- matematikai modellek a természet- és társadalom földrajzban;

- földrajzi információs rendszerek;

- számítógépes térképezés.
\end{abstract}

A Magyar Tudományos Akadémia Regionális Kutatások Központja és a Földrajtudományi Kutató Intézet a Nemzetközi Földrajzi Unió Matematikai Modellezési Bizottságának magyar tagozatával karöltve szervezi a VIII. Európai Elméleti- és Kvantitatív Földrajzi Kollokvium elnevezésű rendez-

Az előadások rövid összefoglalójának beadási határideje 1993. január 31. Az összefoglalókat angol nyelven kell elkészíteni, és a kollokvium titkárának kell megküldeni, a következő címre

\author{
Bassa László \\ Magyar Tudományos Akadémia \\ Földrajztudományi Kutató Intézete \\ 1388 Budapest, P. B. 64., Fax: (361) 1317-991
}

A tanácskozás célja: a téma keleti és nyugati szakértőinek találkozása. A kollokvium első ízben kerül megrendezésre Kelet-Közép-Európában.

Tekintettel a térség jelentős elmaradására a korszerú technika alkalmazásában és a térinformatika területén, a kollokvium kiváló lehetőséget kínál a legújabb módszerek alkalmazásának megismerésére, magasabb színvonalú szakmai párbeszéd megkezdésére, és újabb projektek kialakítására. 